Article

\title{
Geodetic Mass Balances and Area Changes of Echaurren Norte Glacier (Central Andes, Chile) between 1955 and 2015
}

\author{
David Farías-Barahona ${ }^{1, *}$, Sebastián Vivero ${ }^{2}$, , Gino Casassa ${ }^{3,4}$, Marius Schaefer ${ }^{5}$, \\ Flavia Burger ${ }^{6}$, Thorsten Seehaus ${ }^{1}$, Pablo Iribarren-Anacona ${ }^{7} \mathbb{D}$, Fernando Escobar ${ }^{4,+}$ and \\ Matthias H. Braun ${ }^{1}$ (D)
}

1 Institut für Geographie, Friedrich-Alexander-Universität Erlangen-Nürnberg, Wetterkreuz 15, D-91058 Erlangen, Germany; thorsten.seehaus@fau.de (T.S.); matthias.h.braun@fau.de (M.H.B.)

2 Institute of Earth Surface Dynamics (IDYST), University of Lausanne, CH-1015 Lausanne, Switzerland; sebastian.viveroandrade@unil.ch

3 Centro de Investigación Gaia Antártica (GIGA), Universidad de Magallanes, Av. Bulnes 01855, Punta Arenas, Chile; gino.casassa@umag.cl

4 Ministerio de Obras Públicas, Dirección General de Aguas (DGA), Morandé 59, Santiago, Chile; fescobar29@gmail.com

5 Instituto de Ciencias Físicas y Matemáticas, Universidad Austral de Chile, Campus Isla Teja, Valdivia 5110566, Chile; mschaefer@uach.cl

6 Department of Geography and Environmental Sciences, Northumbria University, Ellison Building, Newcastle upon Tyne NE1 8ST, UK; flavia.burger@northumbria.ac.uk

7 Instituto de Ciencias de la Tierra, Universidad Austral de Chile, Campus Isla Teja, Valdivia 5110566, Chile; pablo.iribarren@uach.cl

* Correspondence: david.farias@fau.de; Tel.: +49-(0)9131-8522463

+ Presently retired.

Received: 10 January 2019; Accepted: 24 January 2019; Published: 28 January 2019

check for updates

\begin{abstract}
The Echaurren Norte Glacier is a reference glacier for the World Glacier Monitoring Service (WGMS) network and has the longest time series of glacier mass balance data in the Southern Hemisphere. The data has been obtained by the direct glaciological method since 1975. In this study, we calculated glacier area changes using satellite images and historical aerial photographs, as well as geodetic mass balances for different periods between 1955 and 2015 for the Echaurren Norte Glacier in the Central Andes of Chile. Over this period, this glacier lost $65 \%$ of its original area and disaggregated into two ice bodies in the late 1990s. The geodetic mass balances were calculated by differencing digital elevation models derived from several sources. The results indicated a mean cumulative glacier wide mass loss of $-40.64 \pm 5.19 \mathrm{~m}$ w.e. $\left(-0.68 \pm 0.09 \mathrm{~m}\right.$ w.e. $\left.\mathrm{a}^{-1}\right)$. Within this overall downwasting trend, a positive mass balance of $0.54 \pm 0.40 \mathrm{~m}$ w.e. $\mathrm{a}^{-1}$ was detected for the period 2000-2009. These estimates agree with the results obtained with the glaciological method during the same time span. Highly negative mass change rates were found from 2010 onwards, with $-1.20 \pm 0.09 \mathrm{~m}$ w.e. $\mathrm{a}^{-1}$ during an unprecedented drought in Central Andes of Chile. The observed area and the elevation changes indicate that the Echaurren Norte Glacier may disappear in the coming years if negative mass balance rates prevail.
\end{abstract}

Keywords: glacier mass balance; geodetic method; LiDAR; central Andes; glacier mapping; mountain glacier 


\section{Introduction}

Mid-latitude glaciers in the Southern Hemisphere, particularly in South America, are less studied than their northern counterparts [1]. The Echaurren Norte Glacier has the longest and most continuous record of glacier mass balance in the Southern Hemisphere, from 1975 to present. This is particularly relevant as a climate indicator for the Southern Andes. However, glacier mass balance for some Andean regions remains largely unknown, such as in the Central Andes [2]. Therefore, there is a serious lack of information for understanding the impacts of global climate change on glacier behavior in this region [3]. Due to their sensitive response to climatic conditions, glaciers are important indicators of climate change $[4,5]$. Several studies report that most mountain glaciers and ice caps worldwide are retreating and thinning in response to current global warming [6,7].

The Central Andes of Chile $\left(31^{\circ}-35^{\circ} \mathrm{S}\right)$ are characterized by a Mediterranean climate with marked winter and summer seasons. Winter precipitation is caused by predominant westerly circulation and the orographic enhancement by the Andes. Precipitation displays a high interannual variability generally associated with El Niño-Southern Oscillation (ENSO) events [8]. Spring runoff is mainly generated by seasonal snow melt, while later in the summer glacier melt becomes more dominant $[9,10]$. Precipitation in Central Chile has decreased since 2010 [11,12] and between 1976 and 2006 a warming of about $+0.25{ }^{\circ} \mathrm{C}$ per decade was detected [13]. In addition, an increase in elevation of the $0{ }^{\circ} \mathrm{C}$-isotherm was observed between 1975 and 2001 [14]. This is associated with a rise of the Equilibrium Line Altitude (ELA) of glaciers in this region [14,15]. Due to these changes, glaciers in the Central Andes have shrunken significantly in recent decades [16,17].

In northern and central Chile, information on glacier mass balance and runoff plays a key role for management of water resources [18]. These have been under increasing pressure during recent decades due to economic and population growth, in addition to droughts [19]. Previous hydrological modelling has highlighted the importance of glaciers in the Maipo river basin at the end of the summer season [20]. The authors estimated that, during the severe drought of $196967 \%$ of the water discharge flowing into the central valley originated from glacier meltwater. This large contribution from glaciers at the end of the summer during extremely dry years was confirmed by more recent studies, which show glacier runoff contributions of $63 \%$ and $67 \%$, respectively [21,22]. However, at a catchment-wide and annual time scale, glacier contribution is less relevant with snowmelt being the main contributor to runoff [22].

The mass balance of Chilean glaciers has been calculated by different methods, ranging from the traditional glaciological method (e.g., [23-25]) to remote sensing techniques (e.g., [26]). Additionally, ice cores can be used as mass balance proxies. These have been extracted from glacier sites such as Cerro Tapado in North-Central Chile [27], Glaciar Nef in the Northern Patagonia Icefield [28], Cerro Gorra Blanca, Glaciar Pío XI and Glaciar Tyndall in the Southern Patagonia Icefield [29]. Numerical simulations of Surface Mass Balance (SMB) driven by reanalysis data have also been used to compute mass balance at a larger spatial scale [30,31]. A brief overview of mass balance data from southern South America $\left(30^{\circ} \mathrm{S}-56^{\circ} \mathrm{S}\right)$ is given by Casassa et al. [32]. However, most of these studies have addressed Patagonian glaciers, with only a few presenting results from the Central Andes despite their hydrological importance. More recently, Masiokas et al. [33] reconstructed the annual mass balance of Echaurren Norte Glacier for the period 1909-2013 using local and regional hydroclimatic data.

In this study, we provide the first comprehensive long-term analysis of Echaurren Norte Glacier from 1955 to 2015. The aims of our paper were firstly to quantify the glacier elevation changes derived from topographic map from 1955, SRTM-C band from 2000, LiDAR from 2009 and 2015. Additionally, we used TanDEM-X data from 2013. Secondly, to report changes in glacier area using satellite images and aerial photographs over the same period. Our final aim was to relate the observed glacial changes with the local meteorological conditions. 


\section{Study Area}

The Echaurren Norte Glacier $\left(33^{\circ} 34^{\prime} \mathrm{S}-70^{\circ} 07^{\prime} \mathrm{W}\right)$ is a small mountain glacier $\left(0.17 \mathrm{~km}^{2}\right.$ in 2015$)$ located in the upper Maipo basin in the Central Chilean Andes, $50 \mathrm{~km}$ east of Santiago (Figure 1). The glacier lies in the headwaters of the Laguna Negra in the Yeso sub-basin, which is one of the highest mountain sub-basin within the upper Maipo basin. The Yeso sub-basin, which includes the Yeso reservoirs, are the main source of freshwater for more than 7 million inhabitants of Santiago and the large-scale agriculture production in the region [34].
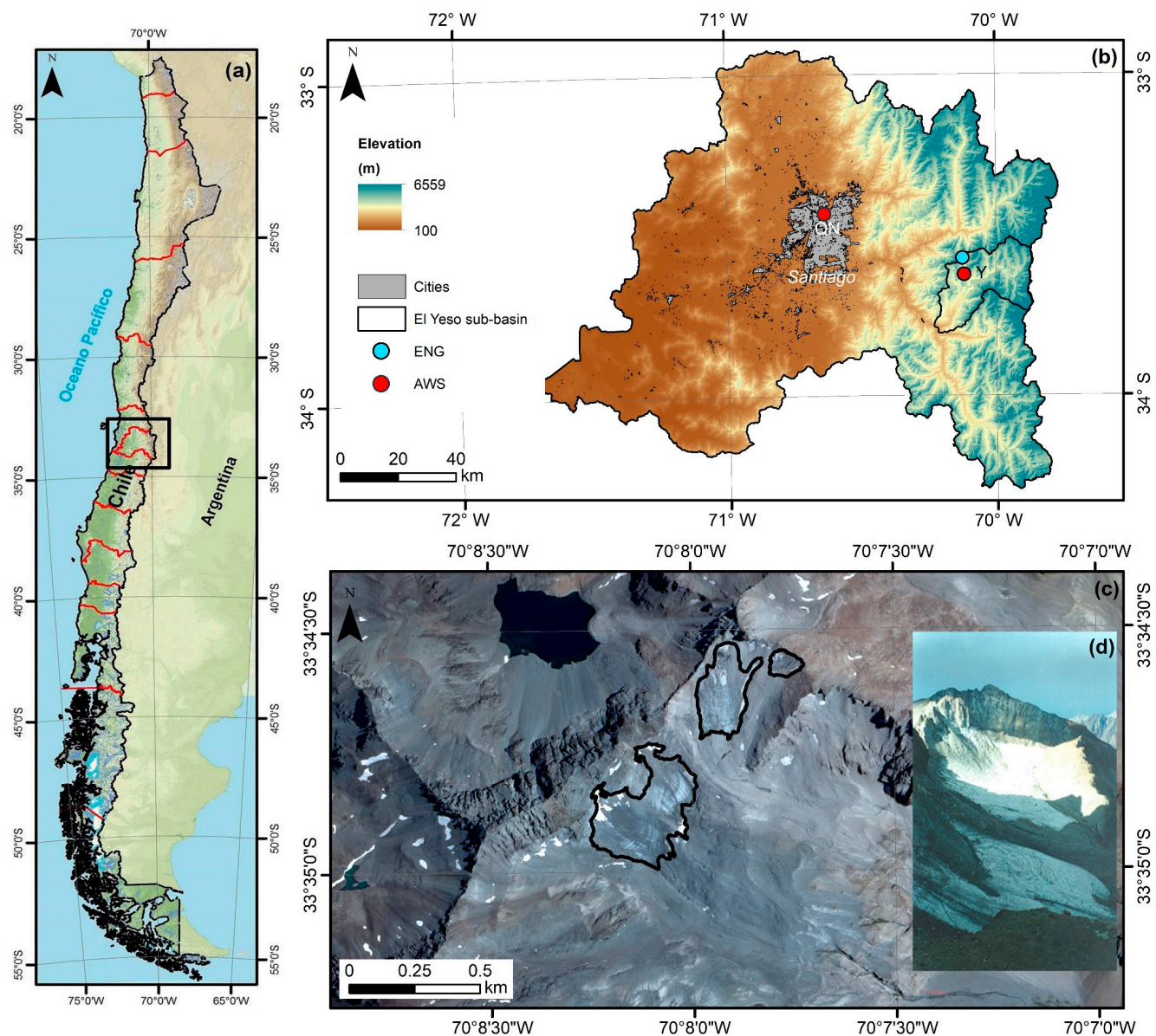

Figure 1. (a) Administrative regional distribution of Chile. (b) Metropolitan Region, Santiago capital of Chile. El Yeso sub-basin (black line). Background Shuttle Radar Topography Mission (SRTM) digital elevation model (USGS). (c) Location of the Echaurren Norte Glacier in the Central Andes of Chile. Glacier area corresponds to 2015. The background is a SPOT satellite image from 30 January 2015 (obtained from the Dirección General de Aguas, DGA). (d) Panoramic photography from west to east in March 1999 (Photo taken by Jorge Quinteros, DGA).

The glacier mass balance measurements at Echaurren Norte Glacier are the longest continuous time series in South America and in the Southern Hemisphere (1975-present). Measurements have been sponsored by the Dirección General de Aguas (DGA) using the direct glaciological method [35]. Computations use the combined system based on the stratigraphic and fixed-date systems, calculated from measurements on fixed calendar rates [36,37]. The hydrological year spans from the 1st of April to the 31st of March, with accumulation and ablation periods defined from April to September and October to March, respectively. Accumulation was calculated by means of a snow pit dug near the center of the glacier. Within the pit, measurements of snow temperature, density and grain size were taken every $20 \mathrm{~cm}$. The data from the snow pit was used as an estimation of the mean accumulation on the glacier [38]. Measurements were normally taken at the beginning of spring, 
close to the 1st of October. However, due to logistic constraints, extrapolation factors were applied to accumulation values when field measurements did not coincide with the beginning of the melt season [39]. The annual accumulation was calculated using the mean snow density and depth to the previous year firn or ice layer at the snow pit. At the beginning of the melt season, an ablation stake network was installed on the glacier, which was measured regularly until the end of summer. At the beginning of the mass balance measurements, 40 stakes were distributed over the glacier surface; however, due to glacier shrinkage in the last decade, especially since 2006, only 18 stakes were placed every year to measure the glacier ablation [39].

\section{Materials and Methods}

\subsection{Glacier Area Changes}

The outlines of the Echaurren Norte Glacier were derived from satellite images and aerial photographs from different sources and quality (Table 1). The oldest aerial photographs available are from the 1955 HYCON photogrammetric survey, a flight campaign carried out as part of an agreement between Chile and the Inter-American Geodetic survey of the United States. In 1961, an agreement between the Organization of American States (OAS/OEA) and the Chilean government led to a photogrammetric survey carried out by the Aero Service Company. Analogue aerial photographs were obtained and subsequently administrated by Servicio Aerofotogramétrico (SAF) of the Chilean Air Force (FACH). Another aerial photograph survey was obtained in 1997 (GEOTEC) by SAF. These aerial photographs were scanned using a photogrammetric scanner at high resolution (1200 DPI). The photos were oriented using fiducial marks, camera calibration data and ground control points (GCPs) derived from a LiDAR dataset from DGA of 2009 and 2015 [40]. The RMSE for the photogrammetric triangulations are $1.2 \mathrm{~m}$ for the 1955 photographs, and $0.9 \mathrm{~m}$ for 1997.

Table 1. Overview of the data sets used for glacier area change mapping. Glacier areas were estimated from the orthorectified and georeferenced images.

\begin{tabular}{cccc}
\hline Date & Survey & Spatial Resolution & Source \\
\hline 24 February 1955 & HYCON aerial photos & $1 \mathrm{~m}$ & IGM \\
1961 & OEA aerial photos & $1 \mathrm{~m}$ & IGM/SAF \\
02 March 1989 & Landsat TM satellite image & $30 \mathrm{~m}$ & USGS \\
05 March 1990 & Landsat TM satellite image & $30 \mathrm{~m}$ & USGS \\
29 March 1993 & Landsat TM satellite image & $30 \mathrm{~m}$ & USGS \\
March 1997 & GEOTEC aerial photos & $1 \mathrm{~m}$ & SAF \\
20 February 2000* & Landsat TM satellite image & $30 \mathrm{~m}$ & USGS \\
28 April 2009 & DGA LiDAR orthophoto & $0.2 \mathrm{~m}$ & DGA \\
30 January 2015 & SPOT satellite image & $1.5 \mathrm{~m}$ & DGA \\
\hline & *Glacier area corresponds to the SRTM acquisition date.
\end{tabular}

In addition, we used optical satellite data from SPOT 6 imagery acquired in January 2015 (RGB-Pansharpened) [41] and several Landsat TM images from between 1989 and 2000. Glacier extent classifications for the multispectral imagery were done by applying a simple band combination approach known as band ratio segmentation using Near Infrared (NIR-TM4) and Shortwave Infrared (SWIR-TM5) bands [42,43]. All datasets were projected to the Universal Transverse Mercator (UTM) $19 S$ zone and WGS-84 Datum. Changes in the glacier extent were measured by manual digitizing from this multitemporal datasets. We considered an error of $5 \%$ of the area for each Landsat satellite image [44]. For aerial photographs and the SPOT image, we considered an error of 1-pixel size uncertainty for the glacier delineation [45]. The consolidated dataset was further refined in conjunction with several photographs acquired during field trips, specifically for glacier area interpretation in 2015 (Figure S1). 


\subsection{Geodetic Mass Balance and Volume Changes}

The geodetic mass balance method provides important information on the current status and evolution of many glaciers worldwide [7]. We obtained the geodetic mass balance derived by DEMs differencing for four periods. Table 2 shows the complete dataset of topographic information, comprising topographic maps, Shuttle Radar Topography Mission (SRTM) and LiDAR products. The study site is covered by historical topographic maps at a 1:50,000 scale, published by the Geographic Military Institute of Chile (IGM) in 1975. The topographic mapping was undertaken using the same aerial photographs as the delineated area (HYCON), with levelling based on a terrestrial theodolite survey to provide vertical and horizontal reference. Several point measurements were used as ground control by the IGM to obtain the maps. The 1975 maps were originally produced in PSAD56 datum, UTM projection 19S, and were adjusted to WGS84 Datum. A digital elevation model (DEM) based on the $50 \mathrm{~m}$ altitude contour lines from the digitalized IGM map was created and resampled, using the kriging interpolation method (e.g., [46]).

Table 2. Overview of the datasets used for glacier elevation changes.

\begin{tabular}{|c|c|c|c|}
\hline Year & Sensor/Products & Nominal Scale/Spatial Resolution & Source \\
\hline 24 February 1955 & $\begin{array}{l}\text { Aerial Camera/Chilean } \\
\text { topographic maps }\end{array}$ & $1: 50,000$ & IGM \\
\hline 11-22 February 2000 & SRTM C-band & $30 \mathrm{~m}$ & USGS/NASA \\
\hline 28 April 2009 & LiDAR (Mark II) & $1 \mathrm{~m}$ & DGA/Terra RSL \\
\hline 27 January 2013 & TanDEM-X & $30 \mathrm{~m}$ & DLR \\
\hline 23 February 2015 & LiDAR (Harrier 68i) & $1 \mathrm{~m}$ & DGA/Digimapas \\
\hline
\end{tabular}

In addition, we used SRTM C-band data in this study. The SRTM dataset was comprised of interferometric synthetic aperture radar (InSAR) data that were acquired simultaneously in the C-band and X-band frequencies between the 11th and 22nd of February 2000 [47]. The X-band system operated with a swath width of $\sim 50 \mathrm{~km}$ (C-band $\sim 225 \mathrm{~km}$ ), which does not allow for global data coverage [48].

A $30 \mathrm{~m}$ resolution DEM derived from TanDEM- $X$ data was generated in this study. TerraSAR- $X$ and TanDEM-X (TDX) is an ongoing (bi-static) satellite constellation launched and operated jointly by the German Aerospace Center (DLR) and EADS Astrium. We followed the TanDEM-X processing scheme as described in $[49,50]$ using GAMMA software and own code. The SRTM-C DEM was used as a reference DEM for the InSAR processing. The topographic phase was simulated from the SRTM-C DEM using TanDEM-X interferometric parameter to obtain the double difference interferogram. Noise in the interferogram was suppressed using a Goldstein filter [51]. Areas degraded due to shadow and water bodies (coherence $<0.2$ ) were masked out before unwrapping the differential phase. We unwrapped the phase using a Minimum Cost Flow (MCF) algorithm [52]. It was ensured that no phase jumps (or residual phase) remained before converting the unwrapped phase into differential height; the SRTM-C reference DEM was then re-added to the differential heights. Finally, to mosaic, we applied a sequence of a concatenation of all raw DEM scenes using a stable ground mask derived from optical data and correct all vertical bias applying a polynomial fitting [53].

Additionally, two airborne laser altimetry (LiDAR) campaigns in April 2009 and February 2015 have been sponsored by DGA. The LiDAR points have a vertical accuracy of $\pm 0.3 \mathrm{~m}$, calculated from the simultaneous comparison with ground GNSS measurements performed on- and off-glacier areas [41,54]. We generated two DEMs from the LiDAR point cloud data using a Triangulated Irregular Network (TIN) interpolation method in ArcGIS 10.1, achieving $1 \mathrm{~m}$ of spatial resolution for each year. In order to keep consistency between the datasets, elevation values were converted to a common vertical reference system in orthometric heights (EGM96 geoid).

In order to obtain accurate and reliable values among potentially misaligned DEMs, we extensively reviewed the three-dimensional (3-D) orientation of all DEMs used in this study. Each DEM was horizontally and vertically co-registered following the universal approach by Nuth and Kääb [55]. 
This approach corrects systematic horizontal and vertical shifts based on the relation between elevation differences as a function of aspect and terrain slope extracted from reference points on stable surfaces. Finally, elevation changes were converted to mass balance by assuming a density scenario of $850 \pm 60 \mathrm{~kg} \mathrm{~m}^{-3}$ [56].

\subsection{Accuracy and Uncertainties}

The uncertainty in elevation change was estimated on stable ground outside the glacier area. We assumed that these areas did not change in elevation during our study period. In order to remove outliers, a mask which contains only elevation points ranging from 2500 to $3900 \mathrm{~m}$ a.s.l. was generated. For all LiDAR post-processing we used the $2015 \mathrm{LiDAR}$ data as reference. Both LiDAR data surveys of 2009 and 2015 were acquired with the same nominal vertical accuracy $( \pm 0.3 \mathrm{~m})$ (Table 1). The comparison on stable areas on slopes $<40^{\circ}$ after the horizontal and vertical co-registration procedure resulted in a relative vertical error of $\pm 3.0 \mathrm{~m}$ between 1955 and 2000, $\pm 4.2 \mathrm{~m}$ between 2000 and 2009, and $\pm 0.3 \mathrm{~m}$ between 2009 and 2015.

Since previous studies using SRTM and TanDEM-X data for the Southern Hemisphere acquired in the austral summer for the Southern Hemisphere reported minimal snow and ice penetration, and due to elevation bias due to SAR signal penetration in snow and ice [57], we compared SRTM-C and X band elevation over 20 glaciers located further south of the Echaurren Norte Glacier after respective co-registration of the DEMs [55]. We did not observe elevation difference that we could attribute to radar signal penetration (Figure S2). This indicated that melt conditions prevailed in the Central Andes during X- and C-band summer SRTM acquisitions on glacier surfaces up to $4000 \mathrm{~m}$, preventing significant signal penetration (e.g., [57-59]) (Figure S2). Landsat imagery from the year 2000 shows a minimal snow cover in the areas surrounding the Echaurren Norte Glacier, confirming that all the winter snow had ablated (e.g., [21]). We assumed similar acquisition conditions for the TanDEM-X dataset with negligible radar signal penetration. This assumption was also supported by the increase of debris cover until 2015.

Hence, the mass balance inaccuracy was calculated using the equation of error propagation (Equation (1)), including the following uncertainties (e.g., [53]):

$$
d \mathrm{M}=|\mathrm{M}|^{*} \sqrt{\left[\frac{\delta_{\frac{d h}{d t}}}{\frac{d h}{d t} \text { total }}\right]^{2}+\left[\frac{\delta_{A}}{A}\right]^{2}+\left[\frac{\delta_{\rho}}{\rho}\right]^{2}}
$$

Here, $(d \mathrm{M})$ is the uncertainty in mass balance $(\mathrm{M}),\left(\delta_{d h / d t}\right.$ total) the mean error of elevation change over stable ground. This mean uncertainty corresponds to the residual after co-registration on stable areas. (A) denotes the glacier area and $\left(\delta_{A}\right)$ the uncertainty for the glacier extent mapping (Table 1 ). We considered a density uncertainty $\left(\delta_{\rho}\right)$ of $\pm 7 \%$, which corresponds to $\pm 60 \mathrm{~kg} \mathrm{~m}^{-3}$ [56].

For TanDEM-X, error assessment was done using the error approach given by Malz et al. [53]. This used the Median Absolute Deviation (MAD) calculated for each $5^{\circ}$ slope bin:

$$
M A D_{A w}=\frac{\sum M A D_{s l p i} * A_{s l p i}}{A}
$$

Equation (2) shows the performance for the area weighted $\left(M A D_{A w}\right)$, where $\left(M A D_{\text {slpi }}\right)$ corresponds to each $M A D$, (A) corresponds to the total analysed area and $\left(A_{s l p i}\right)$ is the area covered by each slope bin. The $M A D_{A w}$, is equivalent to $\delta d h / d t$ total [53].

\section{Results}

\subsection{Area Change}

A substantial reduction of the glacier surface was observed during the last 60 years. The Echaurren Norte Glacier lost $65 \%$ of its original size to $0.49 \pm 0.01 \mathrm{~km}^{2}$ between 1955 and 2015 (Figure 2). Between 
1955 and 1961, the glacier experienced little change $\left(-0.01 \mathrm{~km}^{2}\right)$. However, a marked retreat was detectable since 1961. The satellite image sequence between 1989 and 1993 shows the progression of a fragmentation of the glacier body. By 1997, the glacier had completely fragmented into two smaller sections with a total area of $0.330 \pm 0.005 \mathrm{~km}^{2}$, displaying a high abundance of surface debris. These changes are also clearly visible in photographs taken during mass balance measurements from 1999 (Figure 1d). In 2009, the area covered by the glacier was $0.280 \pm 0.001 \mathrm{~km}^{2}$, while in 2015 , only $0.170 \pm 0.003 \mathrm{~km}^{2}$ remained.
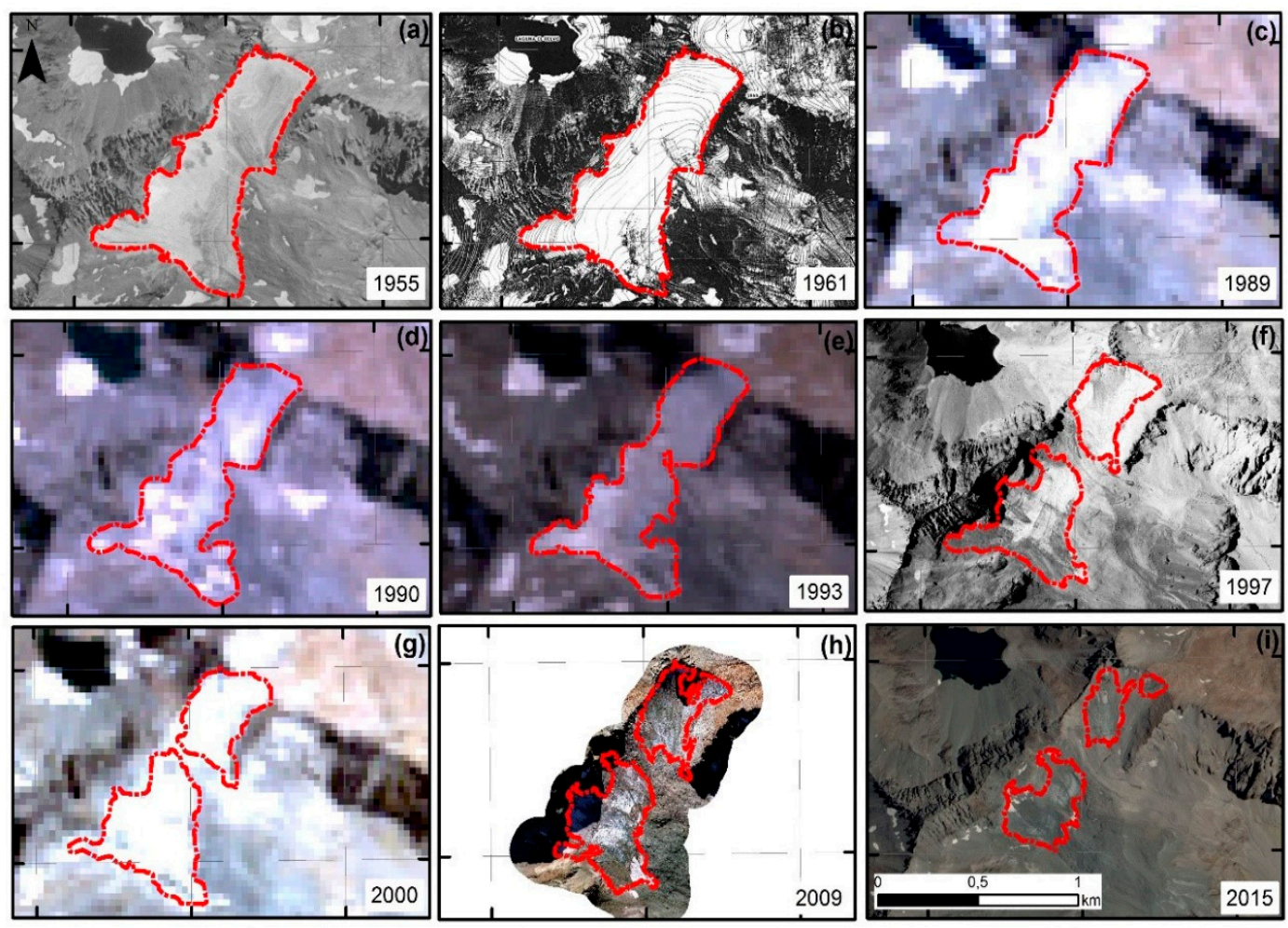

Figure 2. Area changes in the Echaurren Norte Glacier between 1955 and 2015. (a,b,f,h) corresponds to aerial photographs, (c-e,g) Landsat TM images (321 band composite) and (i) SPOT image. Note that in the late 1990s the glacier split up in two smaller ice bodies that are being gradually covered by debris. (See Table 1 for details)

\subsection{Glacier Mass Balance and Volume Change}

Figure 3 shows the spatial distribution of surface elevation change maps for the period 1955-2015. Our results reveal that the Echaurren Norte Glacier shows considerable downwasting from 1955 to 2015 , with a cumulative glacier mass balance of $-40.64 \pm 5.19 \mathrm{~m}$ w.e.

The geodetic mass balances show heterogenous patterns during the different sub-periods. Glacier mass balance and volume changes are summarized in Table 3. Our results showed that the Echaurren Norte Glacier experienced the highest cumulative mass loss between 1955-2000 (Table 3, Figure 3a). Between 2000 and 2009, we obtained a slight positive mass balance in contrast with the period of 2000-2013, where a negative glacier mass balance was obtained (Figure 3b). During 2009 and 2015, the Echaurren Norte Glacier showed the most negative mass balance rates of the whole study period 1955-2015. In comparison with the 2000-2013 period, the rates more than tripled with $-1.20 \pm 0.09 \mathrm{~m}$ w.e. $\mathrm{a}^{-1}$ (Figure 3c,d). At the same time, the Echaurren Norte Glacier showed a general increase in debris cover, mainly in the medial zone (Figures 2 and 3 ). 


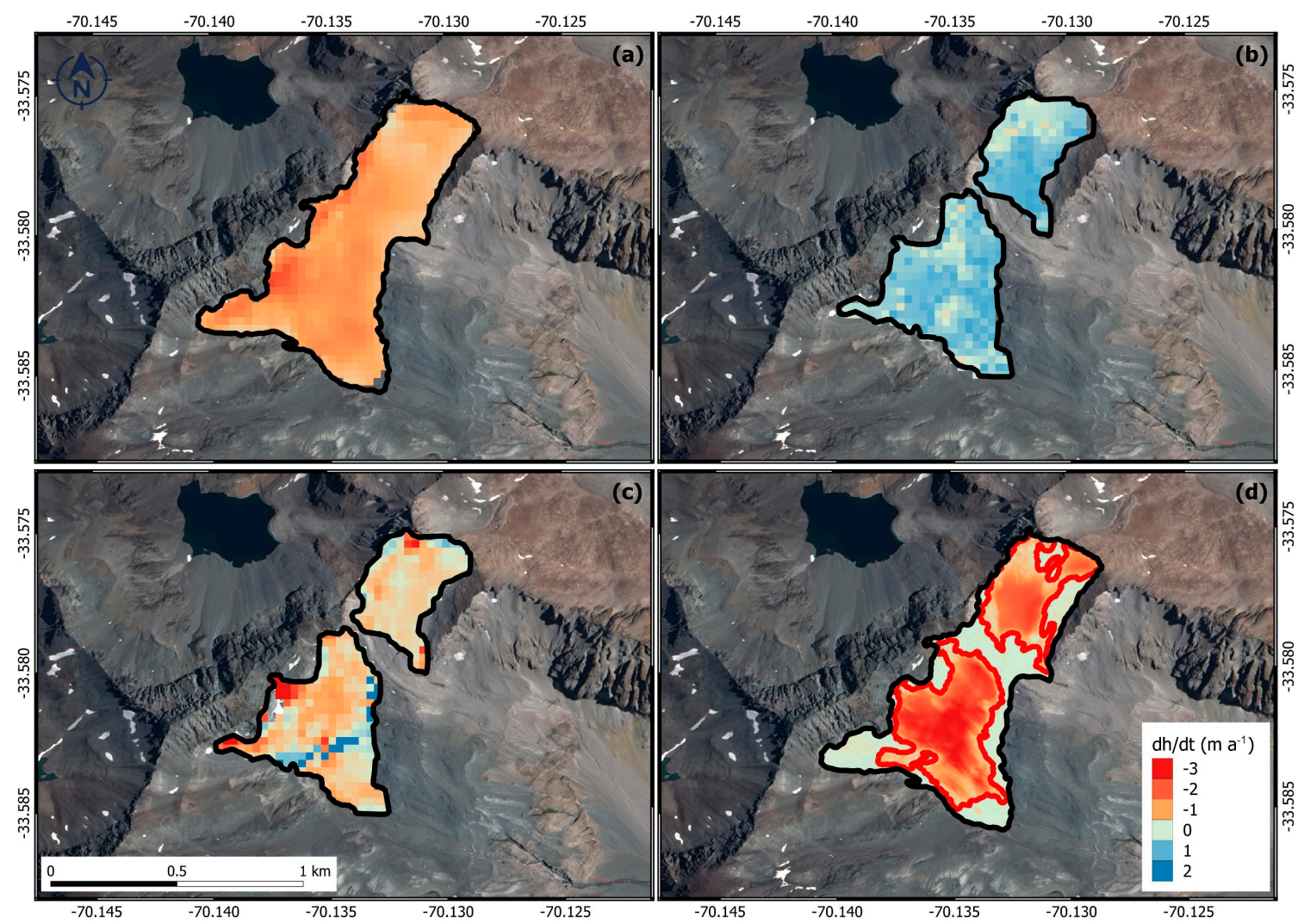

Figure 3. Glacier elevation change rate maps (dh/dt). (a) Elevation difference map for 1955 to 2000. (b) Elevation difference between 2000 and 2009. (c) Elevation difference map for 2000 to 2013. (d) Elevation differences between 2009 and 2015 (Black outline 1955 area, red outline 2009 area).

Table 3. Summary of volume changes and geodetic mass balances for each observation period. We assumed an ice density of $850 \mathrm{~kg} \mathrm{~m}^{-3}$.

\begin{tabular}{cccc}
\hline Period & Volume Change $\left.\mathbf{( k m}^{\mathbf{3}}\right)$ & $\begin{array}{c}\text { Geodetic Mass Balance } \\
\text { (m w.e.) }\end{array}$ & $\begin{array}{c}\text { Geodetic Mass Balance } \\
\text { (m w.e. } \mathbf{a}^{\mathbf{- 1}} \text { ) }\end{array}$ \\
\hline $1955-2000$ & $-0.0220 \pm 0.0010$ & $-38.29 \pm 3.72$ & $-0.85 \pm 0.08$ \\
$2000-2009$ & $0.0020 \pm 0.0010$ & $4.87 \pm 3.59$ & $0.54 \pm 0.40$ \\
$2000-2013$ & $-0.0020 \pm 0.0005$ & $-4.64 \pm 1.10$ & $-0.36 \pm 0.09$ \\
$2009-2015$ & $-0.0020 \pm 0.0001$ & $-7.21 \pm 0.57$ & $-1.20 \pm 0.09$ \\
\hline
\end{tabular}

\section{Discussion}

\subsection{Comparison with Other Studies}

Glaciers have experienced a significant retreat and thinning in the Central Chilean Andes (e.g., [17,24,32,60]) and other parts of the Andes (e.g., [7,61]). However, this negative trend has been occasionally interrupted by periods with positive mass balance (e.g., [24,33]). Our mass balance observations for the Echaurren Norte Glacier are in line with other studies. Figure 4a,b compares modeled mass balance [33] with glacier mass balances from the glaciological and geodetic approaches. In general, we observed a difference between values obtained from glaciological and geodetic methods. However, for the 2000-2013 period, a good agreement between our results and the measurements can

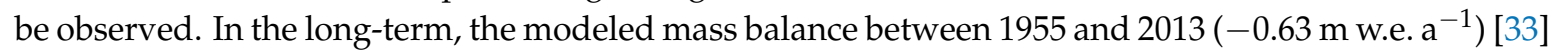
was similar to our geodetic rate of $-0.68 \pm 0.09 \mathrm{~m}$ w.e. $\mathrm{a}^{-1}$ (1955-2015). Masiokas et al. [33] identified several positive mass balances years at the Echaurren Norte Glacier, which coincident

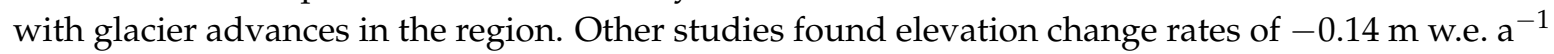
and $-0.20 \mathrm{~m}$ w.e. $\mathrm{a}^{-1}$ at the Yeso and Bello glaciers in the Maipo Basin between 2012 and 2014 [62], 
which is similar our values rates between 2000-2013. We attributed this difference to the altitude of those glaciers, which are located up to $4000 \mathrm{~m}$ a.s.l.
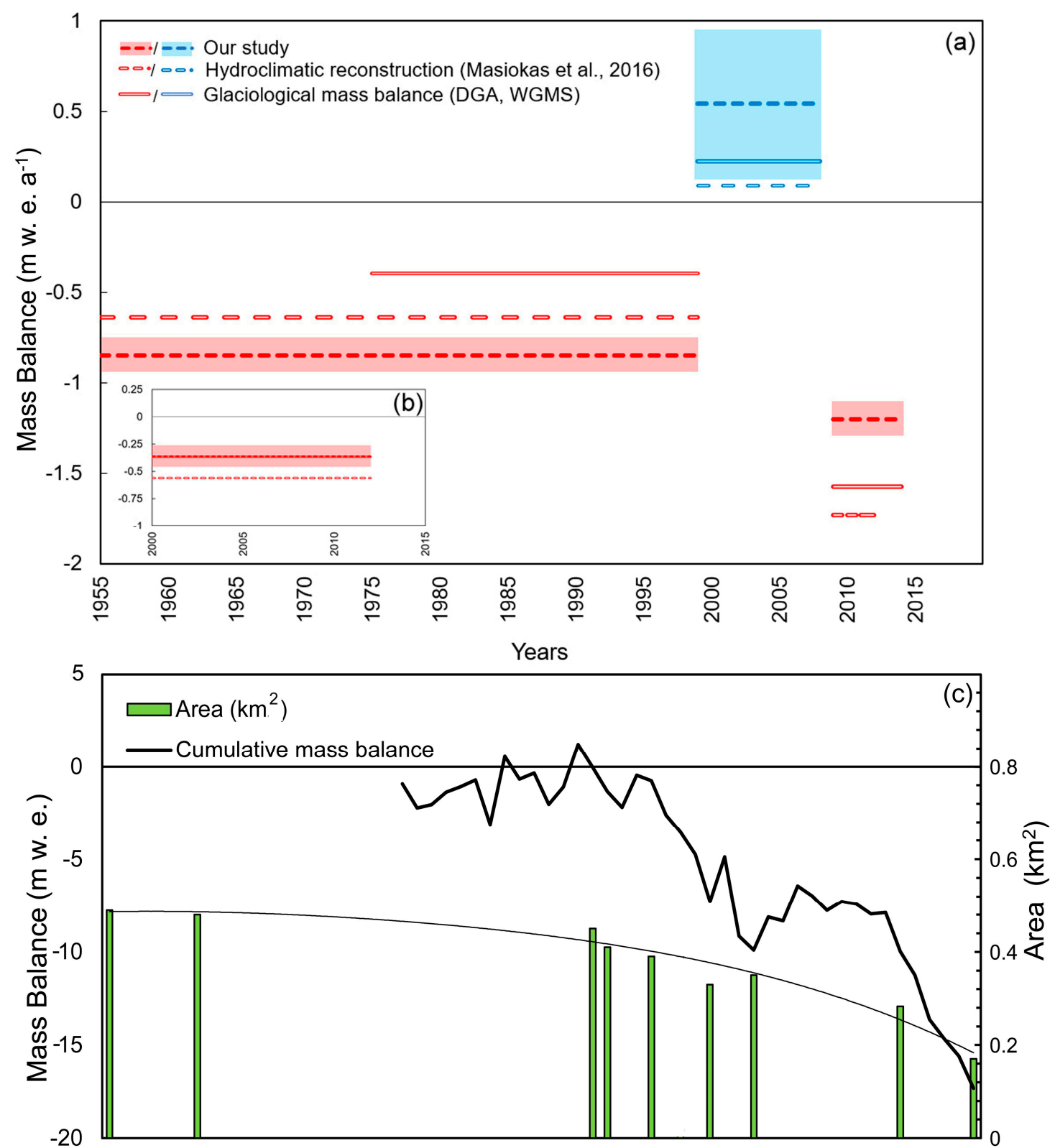

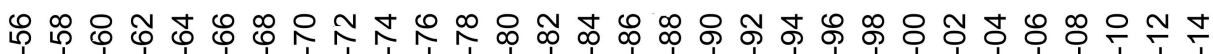

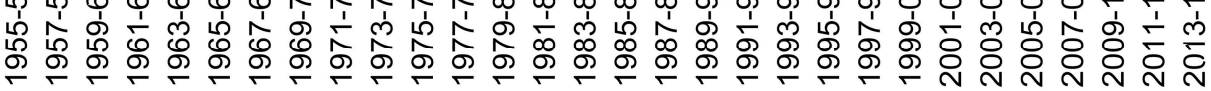

Years

Figure 4. (a) Compilation of different mass balances data between 1955 and 2015. Comparison between mean annual mass balances (Glaciological method, WGMS) with the mean glacier mass balance derived from the hydroclimatic reconstruction from Masiokas et al., [33] and the geodetic mass balance with uncertainty estimations in transparent (cyan and red). (b) Comparison between 2000-2013. (c) Areal changes and the cumulative mass balance of Echaurren Norte Glacier (WGMS) from 1955 to 2015.

Malmros et al. [17] reported a mean area reduction of 30\% in the period 1955-2013 for six major glaciers in the Olivares sub-basin (located $50 \mathrm{~km}$ north of Echaurren Norte Glacier). These six glaciers were larger than $5 \mathrm{~km}^{2}$ in 2013. One of these glaciers, Olivares Alfa Sur, showed a remarkable area loss of $63 \%$ in the period, related at least partially to the northern aspect of the glacier. This reduction 
is similar to the $65 \%$ area loss of Echaurren Norte Glacier in the same period, coincident with the cumulative glacier downwasting (Figure 4c). Echaurren Norte Glacier has a south-eastern aspect and an altitude ranging from $3650 \mathrm{~m}$ to $3900 \mathrm{~m}$ a.s.l, whereas the glaciers around the Olivares basin have mean elevations of $\sim 4500 \mathrm{~m}$ a.s.l.

Reported glaciological mass balances should be homogenized to minimize errors due to differences in operators and calculation methods [63]. However, due to the lack of access to the original stakes, we could only compare general trends observed by geodetic and glaciological mass balance. We used the glaciological mass balance data reported by DGA during four-time periods for which DEMs were available (Figure 4a). For the earliest observation periods, data from each method was not directly comparable, as glaciological monitoring started in 1975 only. For the period of 1975-2000, the glaciological mass balance showed a mean rate of $-0.40 \mathrm{~m}$ w.e. $\mathrm{a}^{-1}$, whereas for $1955-2000$, the observed mean geodetic mass balance rate was $-0.85 \mathrm{~m}$ w.e. $\mathrm{a}^{-1}$ (Table 3 ). This difference of $-0.45 \mathrm{~m}$ w.e. $\mathrm{a}^{-1}$ could be explained by the difference in time span between these two estimates, alongside density factors and the uncertainty estimation.

Between 2000 and 2009, the average glacier mass balance observed by the glaciological method showed the same positive trends with the geodetic mass balance. The DGA glaciological mass balance data available from WGMS identified four positive mass balance seasons, 2000-2001, 2002-2003, 2005-2006 and 2008-2009, that also coincident with positive and neutral phases of ENSO (Figure 5). This indicates that the positive mass balance years led to an overall positive mass balance for the entire period. The difference in magnitude between both methods could be caused by the assumption that the snow pit is representative for the whole glacier. Since the 1990s, the elevation changes started to modify the slope of the location (field observations). The current location of the snow pit is in an area with a higher slope and elevation than the average glacier. After 2008, field campaigns soundings with a steam drill (DGA personal communication) indicated that $\sim 40 \%$ or more snow could be present in areas with gentler slopes than where the snow pit is regularly dug. This difference possibly causes an underestimation of snow accumulation. This may explain the difference in estimations between geodetic and glaciological mass balance methods.

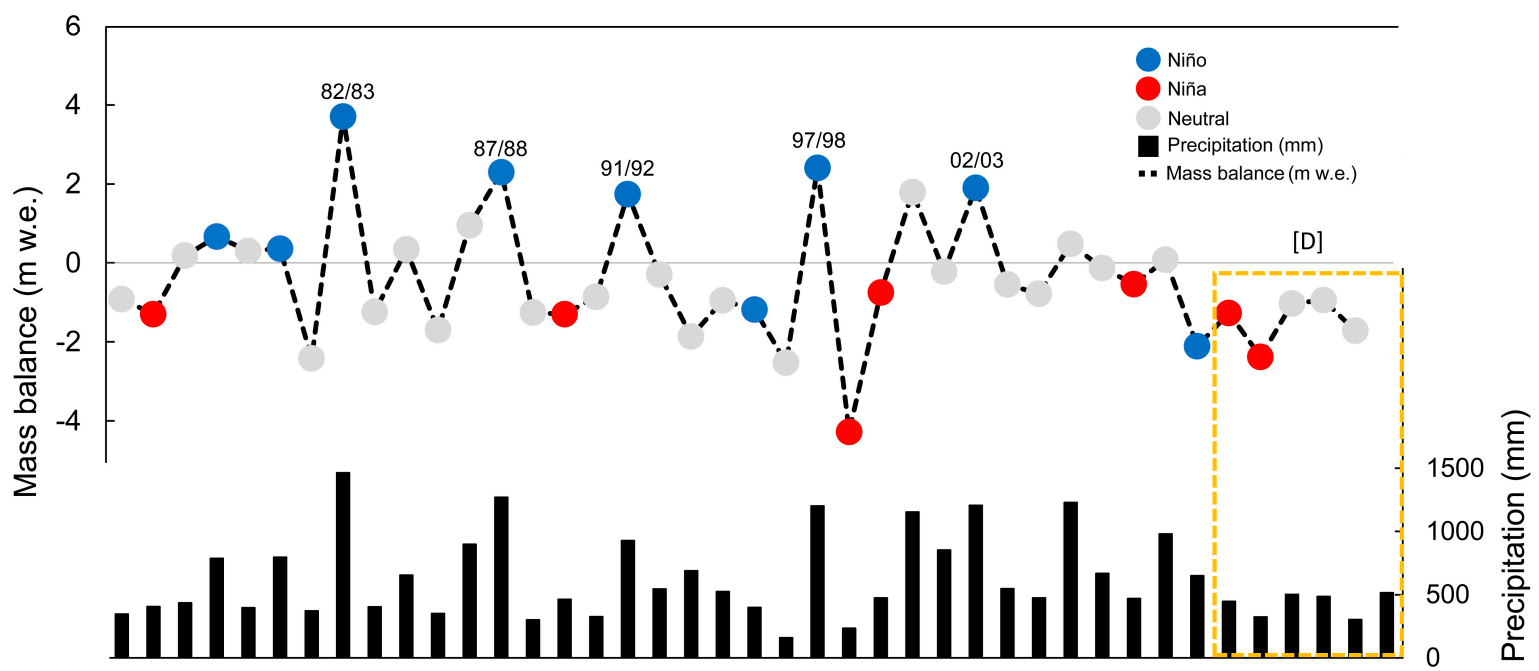

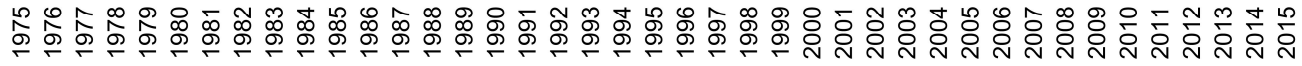

Period

Figure 5. Comparison of the annual mass balance of the Echaurren Norte Glacier between 1975-2015 and annual precipitation between 1975 and 2015 at El Yeso station (black bars). El Niño-Southern Oscillation (ENSO) 3.4 region data were retrieved from the National Ocean and Atmospheric Administration (NOAA). Drought period [D] in orange box [12]. 
Other potential factors of difference between the geodetic and glaciological approaches is that the glaciological mass balance data were collected at different dates due to field work logistics, particularly during the early years of the measurement program [24,39]. Hence, accomplishing the fixed-day system [37] was especially challenging. There was also a lag between the collection of geodetic data and the hydrological year. Finally, we have to consign that our co-registration area for the 2000-2009 was small, where the uncertainty for determination of glacier mass balance represent $\sim 75 \%$ (Table 3 ).

\subsection{Climatic Trends at Maipo Basin}

The climate variability in Central Andes of Chile is partly driven by El Niño-Southern Oscillation (ENSO) events, characterized by irregular fluctuations between warm (El Niño) and cold (La Niña) phases with a periodicity of 2 to 7 years [64]. In the Central Andes El Niño and La Niña crucially determine the interannual variability in precipitation. The Pacific Decadal Oscillation (PDO) is a second driver, which is a pattern of climate variability, visible in the precipitation records over South America on a decadal to inter-decadal scale [64]. A relationship between ENSO and mass balance can be observed in the Echaurren Norte Glacier (Figure 5).

The mechanisms controlling mass balance in this area are still a matter of debate. However, Masiokas et al. [33] observed that the precipitation appears to be the main driver. Early comparisons by Escobar et al. [24] showed that glacier mass balance in Echaurren Norte Glacier between 1975 and 1991 was stronger correlated with precipitation than temperature. We observed the same for the period $1975-2015$ with a high correlation between the precipitation and glacier mass balance $\left(R^{2}=0.73\right)$, and a low correlation with temperature $\left(R^{2}=0.26\right)$ (Figure 6).
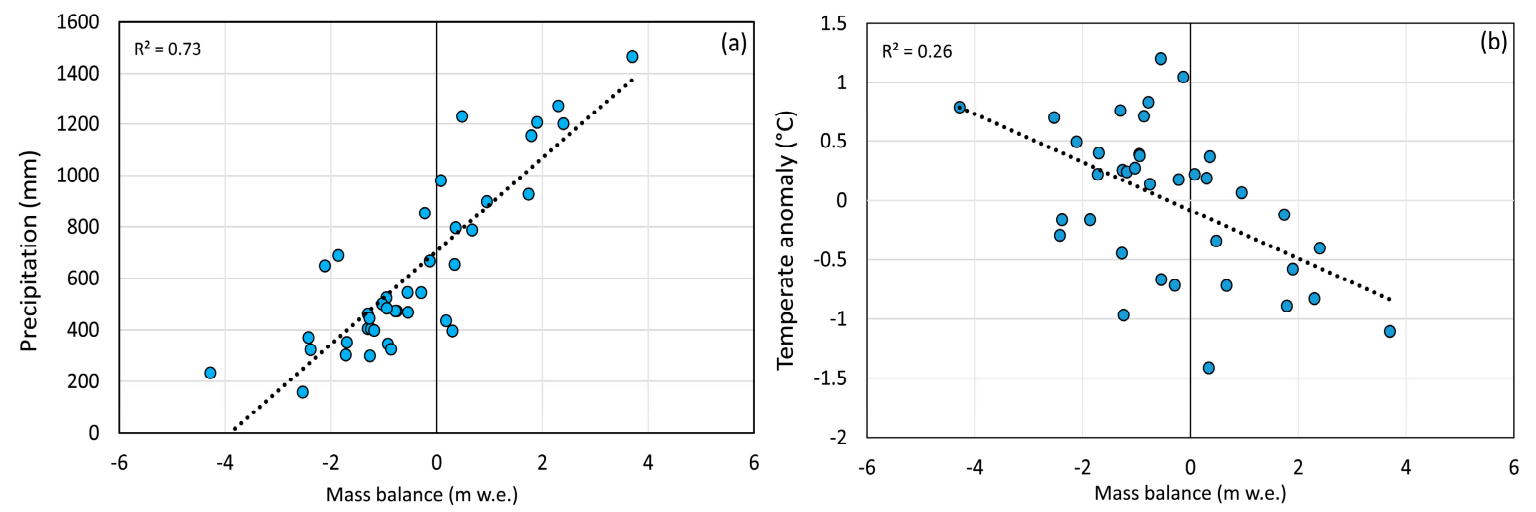

Figure 6. (a) Correlation analysis between glacier mass balance of the Echaurren Norte Glacier with annual precipitation and (b) annual temperature anomalies [65]. It is noteworthy that a higher correlation between mass balance and precipitation is observed (meteorological data from El Yeso weather station, 2474 m a.s.l.).

Previous studies indicated a temperature increase of $+0.25^{\circ} \mathrm{C}$ per decade (significant at the $95 \%$ level) in the period 1979-2006 for the Central Andes of Chile at the El Yeso Embalse weather station (2474 $\mathrm{m}$ a.s.l.) [13]. However, a recent temperature reanalysis showed no significant annual warming between 1979 and 2015 (Figure S3, Table S1) [65], though a significant trend of $+0.43^{\circ} \mathrm{C}$ per decade was measured (21th March-21th June; Figure S4, Table S1).The Quinta Normal station, located in the central valley of Chile (Figure 1 and Figure S4), showed autumn warming as well of $+0.26^{\circ} \mathrm{C}$ per decade during the same period (significant at the 95\% level) [65] (Table S1). In summer and spring, in the valley station mean temperature has been increasing at a rate of 0.15 and $0.18^{\circ} \mathrm{C}$ per decade, respectively (Figure S4). The increase in the autumn temperature could extend the ablation period of the Echaurren Norte Glacier, leading to more negative glacier mass balances [65]. However, we did not observe a correlation between autumn temperature anomalies and glacier mass balance (Figure S5). In support of previous studies [24,33], our results suggest that the glacier mass balance depended mainly on precipitation. 
It is noteworthy that the ELA at the Echaurren Norte Glacier has not been reported in glaciological mass balance calculations [24,33,39]. In fact, the Echaurren Norte Glacier is currently located below the regional ELA, which was located at $\sim 4000 \mathrm{~m}$ a.s.l. at $33^{\circ} \mathrm{S}$ in the Central Andes of Chile in the year 2000 [14]. Therefore, at the end of the summer, ablation takes place over the whole glacier area, resulting in a negative annual mass balance.

In addition to the well-known interannual precipitation variability [66], a drastic drought occurred in Central Chile 2010-2015 (Figure 5 and Figure S3) with an annual rainfall deficit between 25\% and $45 \%$ [12]. This drought probably triggered the observed mass balance deficit of $1.2 \mathrm{~m}$ w.e. $\mathrm{a}^{-1}$ on Echaurren Norte Glacier between 2009 and 2015. Comparing our results between the periods 2000-2009 and 2000-2013 (Figure 4a,b), thinning rates have increased coincident with the drought [12]. Similar trends have also been observed in other studies [33]. The atmospheric dynamics behind this dry period are not clear. However, the negative decrease on precipitation during 2009-2015 was unprecedented [12]. During this period, more neutral El Niño phase were observed (Figure 5), and traditionally dry periods have been associated with La Niña. Under this negative glacier mass balance, a debris cover increase on Echaurren Norte Glacier was recorded over the last decade. This was most likely caused by the ice mass loss, and therefore concentration of debris on the surface [67].

Worldwide, small glaciers $\left(<0.5 \mathrm{~km}^{2}\right)$ account for $\sim 80 \%$ of the total of glaciers number in mid to low-latitudes [68]. Many have lost large percentages of their area during past decades, and this has increased in recent years [1]. For example, over the last four decades, very small glaciers in Switzerland have lost around $70 \%$ of their area [69]. Many of those small glaciers have already vanished. Recent projections for small glaciers in the Swiss Alps indicate that within the next two decades, $52 \%$ will disappear [68]. However, it does not mean that the small glaciers are more vulnerable due to the size. Factors such as aspect, topography, elevation and debris cover may also play a key role [70]. In South America, glacier monitoring on small glaciers is sparse. There are a few small glaciers studied showing generalized retreat and downwasting. For example, Chacaltaya Glacier in Bolivia began shrinking in the early 1980s until its complete disappearance [71,72]. In the last decade, the Conejeras Glacier in Colombia showed an area reduction of $20 \%$ and a negative glacier mass balance of $30 \mathrm{~m}$ w.e. [46]. Although these glaciers examples present a different climate regime than the Echaurren Norte Glacier, this indicates that small glaciers are particularly vulnerable. Hence, under these scenarios, it is expected that the Echaurren Norte Glacier will disappear in the near future if the current negative trends continue. However, in the Central Andes of Chile, more studies on small glaciers are needed.

\section{Conclusions}

This study presents a complete remote sensing and topographic dataset to generate a comprehensive compilation of ice-elevation and area changes from 1955 to 2015 of the Echaurren Norte Glacier. The cumulative mass balance of the glacier for the whole period was $-40.64 \pm 5.19 \mathrm{~m}$ w.e, whereas the total volume lost amounted to $0.022 \pm 0.003 \mathrm{~km}^{3}$ with a reduction of $65 \%$ of the original glacier extent from 1955. Despite slight positive mass balances in 2000-2009, a clear negative long-term trend can be observed. This is consistent with the retreating and thinning trends of glaciers in this region.

The glacier mass balance of the Echaurren Norte Glacier is mainly affected by ENSO variability, showing that the precipitation variability is the main mass-balance driver of the Echaurren Norte Glacier; it seems that temperature is playing a secondary role. However, changes in precipitation patterns (triggered in extreme dry years between 2010 and 2015) between 2009 and 2015 showed that ENSO-neutral periods can also be associated with strong glacier downwasting. If the current mass balance trend continues, we expect that the Echaurren Norte Glacier will disappear in the near future, following the fate of other small Andean glaciers such as Chacaltaya in Bolivia.

Our results are in line with the observed mass loss since 1975 at Echaurren Norte Glacier by glaciological mass balance measurements. However, a reanalysis of glacier mass balance is recommended to homogenize the glaciological mass balance method. 
We provide geodetic mass balance data for a long period of time (60 years) of a small glacier in the Central Andes where, until now, only fragmented studies (temporally and spatially) existed. Future works can unravel the mass-balance of other glaciers in the region considering the cryosphere importance as freshwater resource. Since our results show a daunting fate for the Echaurren Norte Glacier, we want to stress the need for monitoring of other glaciers in the Central Andes of Chile in order to compensate for the potential end of the Echaurren Norte Glacier time series. We want to emphasize the importance of such continuous glacier mass balance data from the region.

Our multi-sensor analysis reveals that sources from historical cartography to modern techniques as LiDAR and InSAR data, combined with a precise post-processing provide reliable datasets to quantify glacier changes over extended periods of time, where in-situ measurements are poor or do not exist.

Supplementary Materials: The following are available online at http:/ / www.mdpi.com/2072-4292/11/3/260/s1. Figure S1: (a) Photographs from the new small lake in center of the Echaurren Norte Glacier, March 2015 (photo by David Farías). (a) Bedrock visible, (b,d) debris cover over the glacier surface, (c) water. Figure S2: Hypsometric plot of the observed SRTM-C and X band penetration difference, average in $100 \mathrm{~m}$ glacier elevation bins. Black box indicates the elevation range of Echaurren Norte Glacier. Since the Echaurren Norte Glacier was not covered by the $\mathrm{X}$ band, we analyzed 20 glaciers located in the same Maipo basin. Figure S3: (a) Annual temperature anomalies at El Yeso weather station and (b) and Quinta Normal station between 1955 and 2015. Significant warming trends were observed in autumn (maximum, minimum and mean values). (c) Annual precipitation at the El Yeso weather station between 1962 and 2015. Since 2010, an uninterrupted drought in Central Andes can be observed. Quality control and procedures of climatic dataset in Burger et al. [66]. Figure S4: (a-d) Mean temperature anomalies per season between 1962 and 2015 in the El Yeso weather station and Quinta Normal (valley) station. Quality control and procedures of climatic dataset in Burger et al. [66]. Figure S5: Correlation analysis between accumulation of Echaurren Norte Glacier and temperature anomalies in (a) winter and (b) autumn. Correlation between ablation of Echaurren Norte Glacier and temperature anomalies in (c) spring and (d) summer. Table S1: Seasonal temperature trends between 1980 and 2015, calculated using a linear least square fit. Quality control and procedures of climatic dataset in Burger et al. [66].

Author Contributions: D.F.-B. processed and analyzed InSAR, LiDAR, maps and optical data and wrote the manuscript. S.V. contributed with area changes data, interpretation and writing. M.H.B. supervised the study, including writing. G.C., M.S. and T.S. provided guidance and feedback throughout the work. F.B. and D.F.-B. processed and prepared the climatic data. F.E. and P.I.-A. contributed with field experience in Echaurren Norte Glacier and interpretation. All co-authors contributed to this study by revising the manuscript and providing a critical discussion of results.

Funding: We thank the financial support by the German Research Foundation DFG under grant BR 2105/14-1, the German Space Agency (DLR) and the Ministry of Economy (BMWi) under contract 50EE1544, and the support by the Chilean National Science Foundation (Fondecyt) under grant agreement $\mathrm{N}^{\circ} 1161130$ "Present and future projections of glacier extent and water yield at Maipo basin in Central Chile".

Acknowledgments: We greatly acknowledge the Chilean Transparency Agency to motivate the former administration of the Glaciology department (DGA) to provide data to this study. The director Crl. J. Riquelme and deputy director Tte. Crl. C. Prado from the Instituto Geográfico Militar (IGM) kindly provided invaluable historical data. Landsat TM and SRTMC were kindly provided by USGS. ENSO 3.4 was retrieved from http:/ / origin.cpc.ncep.noaa.gov/ products/analysis_monitoring/ensostuff/ONI_v5.php. Roland Wastlhuber (KIT) contributed to this study with a first version of the co-registration script. Many thanks to M. Masiokas and WGMS, who provided the modeled and glacier mass balance data. D. Farías and F. Burger acknowledge the support from National Committee Sciences and Technology of Chile (CONICYT) through the Chilean scholarship program for both PhD studies. D. Farías thanks project F413 and Fränkischen Geographischen Gesellschaft for founding a field trip. The University of Erlangen-Nuremberg supported this study from its Open Access Publishing fund. This work is dedicated to the DGA pioneers who started the glacier monitoring program in Chile, special mention to Humberto Peña, Javier Narbona, Fernando Escobar, Fernando Vidal (RIP), Jorge Quinteros, Antonio Vergara, Paulino Aguilera, Gustavo Freixas, Raúl Anabalón (RIP) and Alberto Peralta. Finally, we thank the editor and the three anonymous reviewers that provided important comments to substantially improve this manuscript.

Conflicts of Interest: The authors declare no conflict of interest. The founding sponsors had no role in the design of the study; in the collection, analyses or interpretation of data; in the writing of the manuscript and in the decision to publish the results. 


\section{References}

1. WGMS. Global Glacier Change Bulletin No. 2 (2014-2015); Zemp, M., Nussbaumer, S.U., Gärtner Roer, I., Huber, J., Machguth, H., Paul, F., Hoelzle, M., Eds.; ICSU(WDS)/IUGG(IACS)/UNEP/UNESCO/WMO; World Glacier Monitoring Service: Zurich, Switzerland, 2017; 244p. [CrossRef]

2. Casassa, G.; Haeberli, W.; Jones, G.; Kaser, G.; Ribstein, P.; Rivera, A.; Schneider, C. Current status of Andean glaciers. Glob. Planet. Chang. 2007, 59, 1-9. [CrossRef]

3. Vaughan, D.G.; Allison, I.; Carrasco, J.; Kaser, G.; Kwok, R.; Mote, P.; Murray, T.; Paul, F.; Ren, J.; Rignot, E.; et al. Observations: Cryosphere. In Climate Change 2013: The Physical Science Basis; Contribution of Working Group I to the Fifth Assessment Report of the Intergovernmental Panel on Climate Change; Stocker, T.F., Qin, D., Plattner, G.K., Tignor, M., Allen, S.K., Boschung, J., Nauels, A., Xia, Y., Bex, V., Midgley, P.M., Eds.; Cambridge University Press: Cambridge, UK; New York, NY, USA, 2013.

4. Oerlemans, J.; Reichert, B.K. Relating glacier mass balance to meteorological data by using a seasonal sensitivity characteristic. J. Glaciol. 2000, 46, 1-6. [CrossRef]

5. Kaser, G.; Cogley, J.G.; Dyurgerov, M.B.; Meier, M.F.; Ohmura, A. Mass balance of glaciers and ice caps: Consensus estimates for 1961-2004. Geophys. Res. Lett. 2006, 33, L19501. [CrossRef]

6. Kaltenborn, B.P.; Muhammed, A.; Lamadrid, A.; Benn, D.; Kaser, G.; Paul, F.; Koboltschnig, G.; Casassa, G.; Reynolds, J.M.; Hagen, J.O.; et al. High Mountain Glaciers and Climate Change: Challenges to Human Livelihoods and Adaptation; Nellemann, V., II, Ed.; United Nations Environment Programme; Birkeland Trykkeri AS: Birkeland, Norway, 2010; ISBN 978-82-7701-087.

7. Zemp, M.; Frey, H.; Gärtner-Roer, I.; Nussbaumer, S.U.; Hoelzle, M.; Paul, F.; Haeberli, W.; Denzinger, F.; Ahlstrøm, A.P.; Anderson, B.; et al. Historically unprecedented global glacier decline in the early 21st century. J. Glaciol. 2015, 61, 745-762. [CrossRef]

8. Montecinos, A.; Aceituno, P. Seasonality of the ENSO-related rainfall variability in central Chile and associated circulation anomalies. J. Clim. 2003, 16, 281-296. [CrossRef]

9. Masiokas, M.; Villalba, R.; Luckman, B.; LeQuesne, C.; Aravena, J.C. Snowpack variations in the central Andes of Argentina and Chile, 1951-2005: Large-scale atmospheric influences and implications for water resources in the region. J. Clim. 2006, 19, 6334-6352. [CrossRef]

10. Garreaud, R. Warm winter storms in Central Chile. J. Hydrometeorol. 2013, 14, 1515-1534. [CrossRef]

11. Boisier, J.P.; Rondanelli, R.; Garreaud, R.; Muñoz, F. Anthropogenic and natural contributions to the Southeast Pacific precipitation decline and recent megadrought in central Chile. Geophys. Res. Lett. 2016, 43, 413-421. [CrossRef]

12. Garreaud, R.; Alvarez-Garreton, C.; Barichivich, J.; Boisier, J.P.; Christie, D.; Galleguillos, M.; LeQuesne, C.; McPhee, J.; Zambrano-Bigiarini, M. The 2010-2015 mega drought in Central Chile: Impacts on regional hydroclimate and vegetation. Hydrol. Earth Syst. Sci. 2017, 21, 6307-6327. [CrossRef]

13. Falvey, M.; Garreaud, R. Regional cooling in a warming world: Recent temperature trends in the southeast Pacific and along the west coast of subtropical South America (1979-2006). J. Geophys. Res. 2009, 114, D04102. [CrossRef]

14. Carrasco, J.; Casassa, G.; Quintana, J. Changes of the $0{ }^{\circ} \mathrm{C}$ isotherm and equilibrium line altitude in central Chile during the last quarter of the 20th Century. Hydrol. Sci. J. 2005, 50, 933-948. [CrossRef]

15. Carrasco, J.F.; Osorio, R.; Casassa, G. Secular trend of the equilibrium-line altitude on the western side of the southern Andes, derived from radiosonde and surface observations. J. Glaciol. 2008, 54, 538-550. [CrossRef]

16. Le Quesne, C.; Acuña, C.; Boninsegna, J.A.; Rivera, A.; Barichivich, J. Long-term glacier variations in the Central Andes of Argentina and Chile, inferred from historical records and tree ring reconstructed precipitation. Palaeogeogr. Palaeoclimatol. Palaeoecol. 2009, 281, 334-344. [CrossRef]

17. Malmros, J.K.; Mernild, S.H.; Wilson, R.; Fensholt, R.; Yde, J.C. Glacier area changes in the central Chilean and Argentinean Andes 1955-2013/2014. J. Glaciol. 2016, 62, 391-401. [CrossRef]

18. Valdés-Pineda, R.; Pizarro, R.; Valdés, J.B.; Carrasco, J.F.; García-Chevesich, P. Spatio-temporal trends of precipitation, its aggressiveness and concentration, along the Pacific coast of South America $\left(36^{\circ}-49^{\circ} \mathrm{S}\right)$. Hydrol. Sci. J. 2015, 61, 2110-2132. [CrossRef]

19. Rosegrant, M.W.; Ringler, C.; McKinney, D.C.; Cai, X.; Keller, A.; Donoso, G. Integrated economic-hydrologic water modeling at the basin scale: The Maipo river basin. Agric. Econ. 2000, 24, 33-46. 
20. Peña, H.; Nazarala, B. Snowmelt-runoff simulation model of a central Chile Andean basin with relevant orographic effects. In Symposium at Vancouver 1987-Large Scale Effects of Seasonal Snow Cover; IAHS Publisher: Vancouver, BC, Canada, 1987; Volume 166, pp. 161-172.

21. Casassa, G.; Apey, A.; Bustamante, M.; Maragunic, C.; Salazar, C.; Soza, D. Contribución hídrica de glaciares en el estero Yerba Loca y su extrapolación a la cuenca del río Maipo. In Proceedings of the XIV Congreso Geológico Chileno, La Serena, Chile, 4-8 October 2015.

22. Ayala, A.; Pellicciotti, F.; MacDonell, S.; McPhee, J.; Vivero, S.; Campos, C.; Egli, P. Modelling the hydrological response of debris-free and debris-covered glaciers to present climatic conditions in the semiarid Andes of central Chile. Hydrol. Processes 2016, 30, 4036-4058. [CrossRef]

23. Rabatel, A.; Castebrunet, H.; Favier, V.; Nicholson, L.; Kinnard, C. Glacier changes in the Pascua-Lama region, Chilean Andes (29 S): Recent mass balance and 50 yr surface area variations. Cryosphere 2011, 5, 1029-1041. [CrossRef]

24. Escobar, F.; Casassa, G.; Pozo, V. Variaciones de un glaciar de montaña en los Andes de Chile central en las últimas dos décadas. Bulletin de l'Institut Français d'Etudes Andines 1955, 24, 683-695.

25. Schaefer, M.; Rodriguez, J.; Scheiter, M.; Casassa, G. Climate and surface mass balance of Mocho Glacier, Chilean Lake District, $40^{\circ}$ S. J. Glaciol. 2017, 63, 218-228. [CrossRef]

26. Willis, M.J.; Melkonian, A.K.; Pritchard, M.E.; Ramage, J.M. Ice Loss Rates at the Northern Patagonian Icefield Derived Using a Decade of Satellite Remote Sensing. Remote Sens. Environ. 2012, 117, 184-198. [CrossRef]

27. Ginot, P.; Kull, C.; Schotterer, U.; Schwikowski, M.; Gäggeler, H.W. Glacier mass balances reconstruction by sublimation induced enrichment of chemical species on Cerro Tapado (Chilean Andes). Clim. Past 2006, 2, 21-30. [CrossRef]

28. Matsuoka, K.; Naruse, R. Mass balance features derived from a firn core at Hielo Patagonico Norte, South America. Arct. Antarct. Alp. Res. 1999, 31, 333-340.

29. Shiraiwa, T.; Kohshoma, S.; Uemura, R.; Yoshida, N.; Matoba, S.; Uetake, J.; Godoi, M.A. High net accumulation rates at Campo de Hielo Patagónico Sur, South America revealed by analysis of a $45.97 \mathrm{~m}$ long ice core. Ann. Glaciol. 2002, 35, 84-90. [CrossRef]

30. Schaefer, M.; Machguth, H.; Falvey, M.; Casassa, G.; Rignot, E. Quantifying mass balance processes on the Southern Patagonia Icefield. Cryosphere 2015, 9, 25-35. [CrossRef]

31. Merlind, S.H.; Liston, G.; Hiemstra, C.; Wilson, R. The Andes Cordillera. Part III: Glacier surface mass balance and contribution to sea level rise (1979-2014). J. Clim. 2016, 37, 3154-3174.

32. Casassa, G.; Rivera, A.; Schwikowski, M. Glacier mass-balance data for southern South America $\left(30^{\circ} \mathrm{S}-56^{\circ} \mathrm{S}\right)$. In Glacier Science and Environmental Change; Knight, P., Ed.; Blackwell: Oxford, UK, 2006; pp. 239-241.

33. Masiokas, M.H.; Christie, D.A.; Le Quesne, C.; Pitte, P.; Ruiz, L.; Villalba, R.; Luckman, B.H.; Berthier, E.; Nussbaumer, S.U.; González-Reyes, A.; et al. Reconstructing the annual mass balance of the Echaurren Norte glacier (Central Andes, $33.5^{\circ} \mathrm{S}$ ) using local and regional hydroclimatic data. Cryosphere 2016, 10, 927-940. [CrossRef]

34. Meza, F.J.; Wilks, D.; Gurovich, L.; Bambach, N. Impacts of Climate Change on Irrigated Agriculture in the Maipo Basin, Chile: Reliability of Water Rights and Changes in the Demand for Irrigation. J. Water Res. Plan. Manag. 2012, 138, 421-430. [CrossRef]

35. Østrem, G.; Brugman, M. Glacier Mass-Balance Measurements: A Manual for Field and Office Work; NHRI Science Report; Arctic Institute of North America: Saskatoon, SK, Canada, 1991.

36. Mayo, L.; Meier, M.; Tangborn, W. A system to combine stratigraphic and annual mass-balance systems: A contribution to the International Hydrological Decade. J. Glaciol. 1972, 11, 3-14. [CrossRef]

37. Cogley, J.G.; Hock, R.; Rasmussen, L.A.; Arendt, A.A.; Bauder, A.; Braithwaite, R.J.; Jansson, P.; Kaser, G.; Möller, M.; Nicholson, L.; et al. Glossary of Glacier Mass Balance and Related Terms; IHP-VII Technical Documents in Hydrology, No. 86, IACS Contribution No. 2; UNESCO-IHP: Paris, France, 2011.

38. Peña, H.; Vidal, F.; Escobar, F. Caracterización del manto nival y mediciones de ablación y balance de masa en Glaciar Echaurren Norte. In Jornadas de Hidrología de Nieves y Hielos en América del Sur; Santiago de Chile, United Nations Educational, Scientific, and Cultural Organization, International Hydrology Programme: Santiago, Chile, 1984; pp. 1-12.

39. DGA. Balance de Masa del Glaciar Echaurren Norte Temporadas 1997-98 a 2008-2009; Technical Report; Fernando Escobar and Cristobal Cox: Santiago, Chile, 2010. 
40. Mikhail, E.M.; Bethel, J.S.; McGlone, J.C. Introduction to Modern Photogrammetry; John Wiley and Sons Inc.: New York, NY, USA, 2001.

41. DGA. Modelo Digital de Elevación de Centros Montañosos y Glaciares de las Zonas Glaciológicas Norte y Centro, Mediante LiDAR Aerotranpsortado; Technical Report; Digimapas: Santiago, Chile, 2015.

42. Paul, F.; Kääb, A.; Maisch, M.; Kellenberger, T.W.; Haeberli, W. The new remote-sensing-derived Swiss glacier inventory: I. Methods. Ann. Glaciol. 2002, 34, 355-361. [CrossRef]

43. Paul, F.; Huggel, C.; Kääb, A. Combining satellite multispectral image data and a digital elevation model for mapping debris-covered glaciers. Remote Sens. Environ. 2004, 89, 510-518. [CrossRef]

44. Paul, F.; Barrand, N.E.; Baumann, S.; Berthier, E.; Bolch, T.; Casey, K.; Frey, H.; Joshi, S.P.; Konovalov, V.; Bris, R.L.; et al. On the accuracy of glacier outlines derived from remote-sensing data. Ann. Glaciol. 2013, 54, 171-182. [CrossRef]

45. Williams, R.; Hall, D.; Sigurosson, O.; Chien, Y. Comparison of satellite-derived with ground-based measurements of the fluctuations of themargins of Vatnajökull, Iceland, 1973-1992. Ann. Glaciol. 1997, 24, 72-80. [CrossRef]

46. Mölg, N.; Ceballos, J.L.; Huggel, C.; Micheletti, N.; Rabatel, A.; Zemp, M. Ten years of monthly mass balance of Conejeras glacier, Colombia, and their evaluation using different interpolation methods. Geogr. Ann. Ser. A Phys. Geogr. 2017, 99, 155-176. [CrossRef]

47. Farr, T.G.; Rosen, P.; Caro, E.; Crippen, R.; Duren, R.; Hensley, S.; Kobrick, M.; Paller, M.; Rodriguez, E.; Roth, L.; et al. The Shuttle Radar Topography Mission. Rev. Geophys. 2007, 45, RG2004. [CrossRef]

48. Hoffmann, J.; Walter, D. How complementary are SRTM-X and-C band digital elevation models? Photogramm. Eng. Remote Sens. 2006, 72, 261-268. [CrossRef]

49. Rankl, M.; Braun, M. Glacier elevation and mass changes over the central Karakoram region estimated from TanDEM-X and SRTM/X-SAR digital elevation models. Ann. Glaciol. 2016, 57, 273-281. [CrossRef]

50. Seehaus, T.; Marinsek, S.; Helm, V.; Skvarca, P.; Braun, M. Changes in ice dynamics, elevation and mass discharge of Dinsmoor-Bombardier-Edgeworth glacier system, Antarctic Peninsula. Earth Planet. Sci. Lett. 2015, 427, 125-135. [CrossRef]

51. Goldstein, R.M.; Werner, C.L. Radar interferogram filtering for geophysical applications. Geophys. Res. Lett. 1998, 25, 4035-4038. [CrossRef]

52. Costantini, M. A novel phase unwrapping method based on network programming. IEEE Trans. Geosci. Remote Sens. 1998, 36, 813-821. [CrossRef]

53. Malz, P.; Meier, E.; Casassa, G.; Jaña, R.; Svarca, P.; Braun, M. Elevation and mass changes of the Southern Patagonia Icefield derived from TanDEM-X and SRTM data. Remote Sens. 2018, 10, 188. [CrossRef]

54. DGA. Levantamiento Topográfico Láser Aerotransportado para los Glaciares Echaurren Norte y San Francisco; Technical Report; Terra Remote Sensing Inc.: Sidney, BC, Canada, 2009.

55. Nuth, C.; Kääb, A. Co-registration and bias corrections of satellite elevation data sets for quantifying glacier thickness change. Cryosphere 2011, 5, 271-290. [CrossRef]

56. Huss, M. Density assumptions for converting geodetic glacier volume change to mass change. Cryosphere 2013, 7, 877-887. [CrossRef]

57. Jaber, W.A.; Floricioiu, D.; Rott, H.; Eineder, M. Surface elevation changes of glaciers derived from SRTM and TanDEM-X DEM differences. In Proceedings of the 2013 IEEE International Geoscience and Remote Sensing Symposium (IGARSS), Melbourne, Australia, 21-26 July 2013; pp. 1893-1896.

58. Falaschi, D.; Bolch, T.; Rastner, P.; Lenzano, M.; Lenzano, L.; Lo Vecchio, A.; Moragues, S. Mass changes of alpine glaciers at the eastern margin of the Northern and Southern Patagonian Icefields between 2000 and 2012. J. Glaciol. 2017, 63, 258-272. [CrossRef]

59. Ruiz, L.; Berthier, E.; Viale, M.; Pitte, P.; Masiokas, M.H. Recent geodetic mass balance of Monte Tronador glaciers, northern Patagonian Andes. Cryosphere 2017, 11, 619-634. [CrossRef]

60. Rivera, A.; Casassa, G.; Acuña, C.; Lange, H. Variaciones recientes de glaciares en Chile. Investig. Geogr. 2000, 34, 29-60. [CrossRef]

61. Leiva, J.; Cabrera, G.; Lenzano, L. 20 years of mass balances on the Piloto glacier, Las Cuevas river basin, Mendoza, Argentina. Glob. Planet. Chang. 2007, 59, 10-16. [CrossRef] 
62. Barcaza, G.; Segovia, A.; Farías, D.; Huenante, J.; Vergara, A.; Gonzalez, D.; Varela, B. Surface elevation change of Andean glaciers in Central Chile, based upon airborne laser altimetry and ground-truth GPS measurements (Abstract 5649). In Proceedings of the 26th International Union Geodesy and Geophysics General Assembly, Prague, Czech Republic, 22 June-2 July 2015.

63. Zemp, M.; Thibert, E.; Huss, M.; Stumm, D.; Rolstad Denby, C.; Nuth, C.; Nussbaumer, S.U.; Moholdt, G.; Mercer, A.; Mayer, C.; et al. Reanalysing glacier mass balance measurement series. Cryosphere 2013, 7, 1227-1245. [CrossRef]

64. Garreud, R.D.; Vuille, M.; Compagnucci, R.; Marengo, J. Present-day South American climate. Palaeogeogr. Palaeoclimatol. Palaeoecol. 2009, 281, 180-195. [CrossRef]

65. Burger, F.; Brock, B.; Montecinos, A. Seasonal and elevation contrasts in temperature trends in Central Chile between 1979 and 2015. Glob. Planet. Chang. 2018, 162, 136-147. [CrossRef]

66. Quintana, J.M.; Aceituno, P. Changes in the rainfall regime along the extratropical west coast of South America (Chile): $30-43^{\circ}$ S. Atmosfera 2012, 25, 1-22.

67. Herreid, S.; Pellicciotti, F.; Ayala, A.; Chesnokova, A.; Kienholz, C.; Shea, J.; Shrestha, A. Satellite observations show no net change in the percentage of supraglacial debris-covered area in northern Pakistan from 1977 to 2014. J. Glaciol. 2015, 61, 524-536. [CrossRef]

68. Huss, M.; Fischer, M. Sensitivity of Very Small Glaciers in the Swiss Alps to Future Climate Change. Front. Earth Sci. 2016, 4, 34. [CrossRef]

69. Fischer, M.; Huss, M.; Barboux, C.; Hoelzle, M. The new Swiss Glacier Inventory SGI2010: Relevance of using high-resolution source data in areas dominated by very small glaciers. Arct. Antarct. Alp. Res. 2014, 46, 933-945. [CrossRef]

70. DeBeer, C.M.; Sharp, M.J. Topographic influences on recent changes of very small glaciers in the Monashee Mountains, British Columbia, Canada. J. Glaciol. 2009, 55, 691-700. [CrossRef]

71. Ramírez, E.; Francou, B.; Ribstein, P.; Descloitres, M.; Guérin, R.; Mendoza, J.; Gallaire, R.; Pouyaud, B.; Jordan, E. Small glaciers disappearing in the tropical Andes: A case-study in Bolivia: Glaciar Chacaltaya (16 S). J. Glaciol. 2001, 47, 187-194. [CrossRef]

72. Berger, T.; Mendoza, J.; Francou, B.; Rojas, F.; Fuertes, R.; Flores, M.; Noriega, L.; Rammalo, C.; Ramirez, E. Glaciares Zongo-Chacaltaya-Charquini Sur. Bolivia $16^{\circ}$ S. Mediciones Glaciológicas, Hidrológicas y Meteorológicas, Año Hidrológico 2004-2005; IRDIHH-SENMAHI-COBEE; Informe Great Ice Bolivia: Bolivia, 2005; p. 171.

(C) 2019 by the authors. Licensee MDPI, Basel, Switzerland. This article is an open access article distributed under the terms and conditions of the Creative Commons Attribution (CC BY) license (http://creativecommons.org/licenses/by/4.0/). 